LUCIUS POSTUMIUS MEGELLUS AT GABII: A NEW FRAGMENT OF LIVY*

The chance discovery of a fragment of parchment has substantially enriched the literary tradition on the Third Samnite War. It deals with an episode in 291 B.C., when the consul Lucius Postumius Megellus ordered his soldiers to carry out work on his the conte. Lucis estatc. The inpors lacking in the other sources

At Gabii, in the archaic period, there were at least four cult areas, one extra-urban. At Gabil, in the archaic period, there were at least four cut areas, one extra-uran The sacredness of Gabii and its territory is also attested in the literary sources. A passage of Varro shows that the ager Gabinus had a special status between those of ager Romanus and ager peregrinus: Gabinus (ager) quoque peregrinus, sed quod auspici habet singularia ab reliquo discretus (Ling. S.J3). Even if it is not possible to define exactly the particular nature of the auspices of Gabii, it is clear that the territory had a special position in augural doctrine.

The fragment in question, then, deals both with an obscure period in the history of Rome and with a city that played a crucial role in Roman religion. It is precisely this combination that justifies further discussion of it. The reference to Gabis is importan for a number of reasons: first, the geomorphology of the ager Gabinus clarifies some details, otherwise obscure, in the other literary sources; second, the presence of Roman private property near a Latin town raises the question of the structure of the territory close to Rome, in the context of the relentless expansion of Rome; finally, the consul's order to two thousand soldiers to work on his land raises a number of issues, other than the traditional one of the abuse of authority, issues sharpened by the location of the incident.

\title{
THE FRAGMENT
}

The fragment was found in 1986, in the medieval monastic centre of Naqlun, near the oasis of the Faiyum. It belonged to a Latin codex and contains, on both sides, remains of two columns of uncial Latin script, which can be dated to the fifth century remains of two columns of uncial Latin script, which can be dated to the fifth century
A.D. The text was published within two years by Benedetto Bravo and Miriam A.D. The text was published within two years by Benedetto Bravo and Mirian
Griffin, who proposed the identification of the fragment with a part of a historical Griffin, who proposed the identification of the fragment with a part of a historical work, probably Book 11 of Livy. ${ }^{3}$ Later studies
Vinchesi confirmed the attribution of the text. ${ }^{4}$

*I should like to thank Professor G. Clemente and Professor M. H. Crawford for their

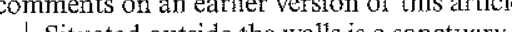
G. Gazzetti, and A. Malizia, Gabii: Rinvenimenti di superficie nell' area della cittò [Rome, 1978] 34), the so-called sanctuary of Juno, and a cult area immediately to the south of the built-up area see M. Guaitoli, 'Gabii. Osservazioni sulle fasi dì sviluppo dell'abitato', QITA 9 (1981), 50, fig. 17 .

P. Catalano, 'Aspetti spaziali del sistema giuridico-religioso romano. Mundus, templum, urbs, age, Latim,

Livio?', Athenaeum 66 (1988)

${ }_{4}^{4}$ R. E. A. Palmer, 'A new fragment of Livy throws light on the Roman Postumii and Latin

(c) The Classical Association 2003, all rights reserved 
The fragment, readable on both sides, reports two different episodes. The text is \begin{tabular}{l}
1 \\
\hline 2 \\
3 \\
4 \\
5 \\
6 \\
7 \\
8 \\
9 \\
10 \\
11 \\
12
\end{tabular}

col. I

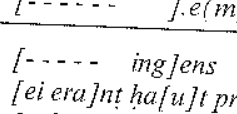

[cul GJabiis lu]rbe. curn

[Grl] lios nouos exer-
Icit lus indictus

le Jusset ibique cen-

lessset ibique cen-
turiati milites es-

sent, cum duob(us)

milib (us) pe[\{.\}] ditum

suom cons [ul? l-2 lett.]

col. I

\begin{tabular}{l}
\hline 2 \\
3 \\
4 \\
5 \\
6 \\
7 \\
8 \\
9 \\
10 \\
11
\end{tabular}

$\begin{array}{ll}2 & j u i \\ 3 & j e \\ 4 & j c a s \\ 5 & j e \\ 6 & \\ 7 & j . \bar{a} \\ 8 & \text { Jnus } \\ 9 & j . . \\ 10 & J i\end{array}$

A.I.3 haluft: that is houd

A.1.5 Gajulos: that is Gatios.

B.Il.10 habiturum: probably the correct form is inhibiturum

Translation of Side A

[he owned - - - - not far from the town of Gabii. Since it was at Gabii that the new army
had been ordered to assemble and since it was there that the sol centuries, (the consul?) set out with two thousand foot soldiers for his own been organized in

Translation of Side $B$

that he will be doing .... as long as he remains in the provincia without his authorization. when he received these orders

Gabii', Athenaeum 78 (1990), 5-18; for M. A. Vinchesi, 'Notizia su un probabile frammento di
'Tito Livio', $A \& R 35$ (1990), 176-82, elements of the frequently used by Livy, especially at the beginning of a new story (haud procul procul Gabiis urbe, The attibution. The other sources are conveniently collected in of the

Bravo and
A comparison between the text of the fragment and the other sources allowed Griffin to identify the two episodes referred to in the fragment with events of the Thir Samnite War, specifically the actions of Postumius Megellus during his thr consulship in 291 B.C. The sources in question are a long excerplum of the Roman Anticuities of Dionysius of Halicarnassus,, an excerptum of Cassius Dio, a passage of the Periocha of the eleventh book of Livy, and an entry in the Suda. The first episode involves the Latin town of Gabii as a theatre of military activity. a new army had been invived to assemble there and organized in centuries, and probably from there ordered to af two thousand soldiers left for the estate, maybe of a consul, located nea contingent $\mathrm{G}$. $\mathrm{B}$ is the final part of a message reported in oratio obliqua and sent to Gabius As well as locating the estate, the author also specifies that the soldiers were pedites."

\section{THE CONSUL'S ESTATE}

The fragment reports that the contingent of soldiers was marching in agrtm suom, The file while the en the first and second line, is incomplete. What came before the sentence [- - ing]ens [ei era]nt halujt pro[cul G]abiis [u]rbe, according to Bravo's

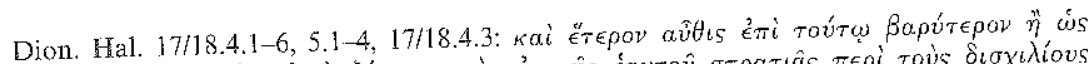

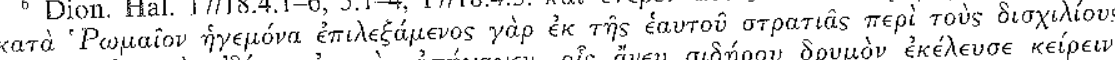
avopas tis tous iolous aypous anypayev,

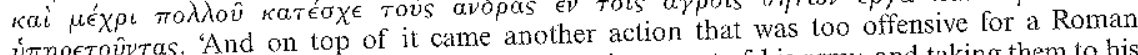
commander. He chose, namely, about two thousand men out of his army, and taking them to his own estate, ordered them to cut down a thicket without iron; and for a long ts slightly revised)

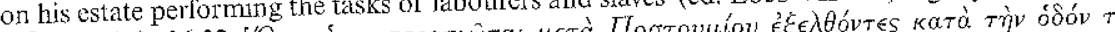

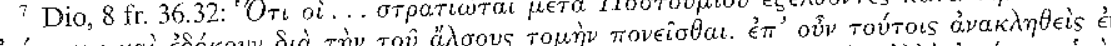

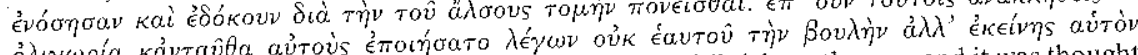
ont their trouble was due to the felling of the grove. Postumius was recalled for these reasons, bu showed contempt for them (the senistors.

his master but hat he was the master of the sonce (cun exercitui pracesset, opera militum in agro

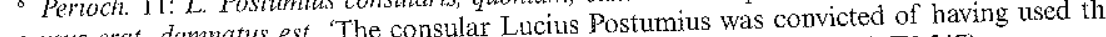
suo usus erat, damn his own land when in command of the army' (ed. Loeb IV 547).

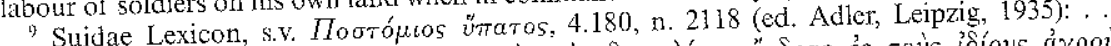

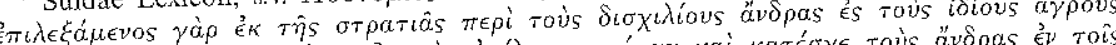

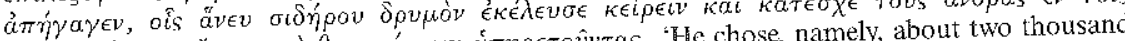

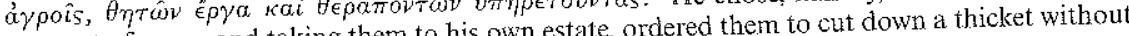
men out of army, and taking thes etate performing the tasks of labourers and slaves.'

iron; and he kep the mon with enough probability the name of the Latin town GJabiis (Stefan (1) following line A.I.5 [ Gajuios instead of Gabios is a banal spelling variant.

Maybe the soldiers used by Postumius were troops of the previous consul Junius Brutus, as seems to emerge from the restoration of the lacunose portion of the the ten letters between oi and

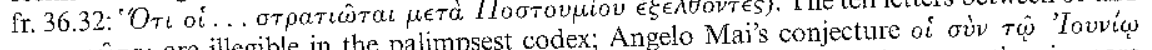

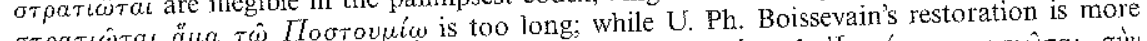
probable, in his edition of Cassius Dio (Berlin, 1895), oi tov lovviov otpartwital auv following E. Cary in the Loeb edition. 
saltus. ${ }^{12}$ The Jatter is more probable, because it ager or, as Griffin suggested, ager et Moreover it fits better with the accounts of it is a frequent combination in Livy. ${ }^{13}$ they report tree-felling on the accounts of Dionysius, Dio, and the Suda, because area to which the word on the estate, which would imply the existence of a wocause repeats Dionysius almost word for word, mention a Donysius and the Suda, which Cassius Dio with the word $\alpha \lambda \sigma_{\sigma o s}$ alludes to the en a $\delta \rho \mu \mu$ s, that is a wood; while word lucus, etymologically linked to $h x$, mo existence of a lucus. ${ }^{14}$ Given that the 'sacred glade', artificially created by bust mean originally not 'sacred wood", but silva), ${ }^{\text {IS }}$ the difference between Diony. consul's estate included a ween Dionysius' $\delta \rho v \mu o ́ s$ and Dio's åd $\lambda$ os suggest (nemus or It is possible that, already in the the containing a lucus were violated in order to obtain more land, as Frontinus assumes for of the peninsula
this case, Megellus'

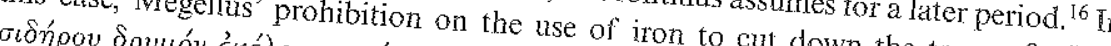
applying a religious $\epsilon v \sigma \epsilon \kappa \epsilon i \rho \epsilon i \nu$, seems to have been an attempt to avees, ois ${ }^{a} \nu \epsilon u$ archaic pray reps suld for the mantenance of land sacred to the avoid sacrilege which meant neported in the de agricultura of Cato ${ }^{18}$ we $k$ to the gods. ${ }^{17}$ From an to be meant sot simple pruning but the felling of trees in that lucum conlucare, disturb by an expiatory sacrifice, to appene the gods to create a lucus, had disturbed by this operation, were sacred ${ }^{19}$ In the ads of gods, to whom the plants, wescription of a sacrifice to Dea Dia to expinte the Fratres Arvales we find the worked on the maintenance of the sacred wood on tools. ${ }^{21}$ Using this metal was normally ford and the necessary introduction of

12 Bravo and Griffin (n. 3), 474

Vinchesi (n. 4), 181.

is F. Coarelli, 'TLG I. I I $581-2$, s.v. ä $\lambda \lambda$ ros.

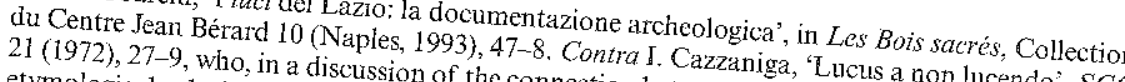
tymological solution lucus a non hu of the connection between lucus and lux n pren lucendo', SCO 16. De controversiis 56.19 The $=87.19$.

${ }^{17}$ Smit (ed. Loeb VIr 33 .

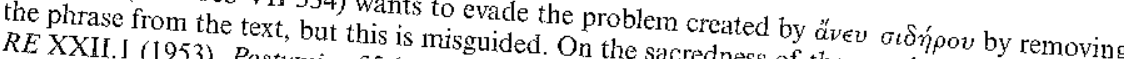
human and divine laws are freque (cc. 935-41), c. 939, who underlines howood, see F. Münzer in ${ }^{18}$ Cato, Agr. 139: lucum conluccare Rualistic accounts of unpopular commanderses against concipito: si deus, si dea est quoiutm illud somano more sic oportet: porco piaculo facito sus

amplins dicito harumque rerum ergo. .. si fodere velis as est porco picculo facere illiusce verba ig On the Italic cuit of trendi causa'. dedicated, see G. Stara-Tedde 'I woods, sometimes identified with the god to who 'Ricerche sulla evoluzione del culto degli alberi del' antica Roma', $B C A R 33(1905), 189-232$ were 129-81. On the definition of a sacred wood, see $I$ srincipio del sec. IV in poi', $B C A R 35$ (1907, formes de Les Bots sacrés (n. 15), 13-20. C Otto 'Sche 'Lucus, nemus: Qu'est-ce qu' (1907) ${ }^{20}$ On the topogrezites Latins', Latomus 59 (2000) 3 . Licus, nemus "bois sacré" et les deux

Frères Arvales, modele du culte public dans la Rome des Emporidus et ses Frères. Le Collège de coinquere, opus facere, see $\mathrm{H}$. Broise to define the maintenance of a sacred 275 (Rome, 1990), Les Bois sacrés (n. 15), I45-57 19-20, etc. Ov. Met. 8741-2:

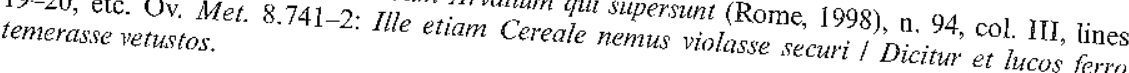

in early Roman religion:22 the sensitivity of the metal to magnetism seemed to hide supernatural properties. ${ }^{23}$ The non-use of iron presumably meant the use of anothe material, such as bronze. ${ }^{24}$ The consul had perhaps acquired land including a sacred wood, but one that was not under the control of a town or of a sanctuary, with an wood, but one that was not under the control of a town or of a sanctuary, with ain encroached on the open space. One possibility is that Postumius, respecting tradition, encroached on the open space. One possibility is that Postumius, respecting tradition, wished to restore a sacred area on his estate. On the other hand it is possible that he wanted to use the labour of his soldiers to clear the wood and use the land for agriculture.

The extra-urban sanctuary to the east of Gabii, ${ }^{25}$ which was in use by the end of the seventh century B.C. or the beginning of the sixth and then abandoned during the midsecond century B.C., ${ }^{26}$ lies along the road to Tibur, towards the Fosso di S. Giuliano. The presence of mineral springs suggests a cult linked to health-giving waters, ${ }^{27}$ but the material in the votive deposit (sitting couples, small babies) suggests rather a goddes of childbirth ${ }^{28}$ The identification of the god of a second sanctuary has been much discussed too. The temple in question lies on a vise on the south side of the Lago di ntre of the network of roads of archaic Latium. The discovery of an antefix with the inscription IVN (Iunonis) seems to confirm the attribution of the sanctuary to Juno. ${ }^{29}$ The sanctuary

${ }^{22}$ E. E. Burris, Taboo, Magic, Spirit. A Study of Primitive Elements in Roman Religion (New A Study in Magic and Retigion, Il, Taboo and the Perils of the Soul (London, 1911), 225-36. On the religious consequences of this prohibition, see E. De Ruggiero, Dizionario epigrafico IV (Rome, 1964), s.v. luctus, $1970 \mathrm{ff}$.

24 M. Cary and A. D. Nock, 'Magic spears', $C Q 21$ (1927), 125-7.

${ }^{24}$ Among the farm tools used for a vineyard, Cato (Agr. 11.4) reports rush-hooks (falces equipment used by Postumius' milites.

${ }^{25}$ F. Castagnoli, 'Santuari e culti nel Lazio arcaico', Archeologia Laziale 3 (1980), 164.7 ; M. Guaitoli, 'Gabii', PP 36 (1981), 152-73; M. Guaitoli and P. Zaccagni, 'Scavi e scoperte 3. Gabii', StEtr 45 (1977), 434-6.

${ }^{26}$ The rebuilding, during the second century B.C., of the so-called sanctuary of Juno, perhap before that period a simple sacellum, dating back to the end of the sixth century B.C, eliminate del Lazio in età repubblicana (Rome, 1987) 11-21: L. Quilici, 'Gabii', in M. Cristofani (ed) L Grande Roma dei Tarquini (Rome, 1990), 159-63.

The function of wells intercepting water-bearing strata with probable therapeutic qualities had already been pointed out by P. Zaccagni, 'Gabii. La città antica ed il territorio', Archeologia Laziale 1 (1978), 44. Moreover that the area was linked to the cult of gods of health may be presence of a sanctuary linked to gods of health, flourishing in the third-second century BC: T. Potter, 'A Republican healing sanctuary at Ponte di Nona', JBAA 138 (1985), 23-47. by lightning in 176 B.C., but dedicated to Apollo (41.16). On the cults of Gabii, see RE VII. (1910), Gabii cc. 420-2 (Weiss); besides the cult of Apollo there was also the cult of Iuno Gabin mentioned by Virgil (Aen. 8.682) and Silius Italicus (12.537), and the cult of Venus Vera Felix (A)

29 M. Almagro Gorbea, El santuario de Juno en Gabii, Excavaciones 1956-1969, Monografia de
a Escuela Esp. de Hist. y Arqueol. 17 (Rome, 1982), 581-624, esp. 595; id., 'Il tempio cosiddetto di Giunone Gabina: situazione attuale dello studio', in Archeologia Lazicle 3 (1980), 168-71; id . 'Larea del tempio di Giunone Gabina nel VI-V secolo a.C., in Archeologia Laziale 4 (1981), 297-304, esp. 302. The presence of votive materials symbolizing beasts of burden, such as oxen C. Lega, 'Topografia dei culti delle divinità protettrici dell'agricoltura e del lavoro dei campi nel 
was apparently frequented from the end of the ninth century B.C.; at the end of the sixth century a sacellum was added, subsequently restored and enlarged certainly during the second century. In the excavations of the sanctuary, an open area, perhaps a grove, was discovered $:^{30}$ the cavities for the trees, perfectly preserved, are visible in the tufa. ${ }^{31}$ An irrigation system was also visible, with a big tank cut in the rock behind the temple and entry points at the two sides; there was also an isolated hole behind the temple, perhaps for a sacred tree, existing from the first phase of the sanctuary and religiously preserved for centuries.

This discovery perhaps confirms the suggestion that Postumius' property included a ucus. Moreover the use of two thousand men, if compared with the small number of labourers suggested by Cato for an olive grove or a vineyard, makes probaber of hypothesis that Postumius' estate was large. ${ }^{32}$

From the literary tradition, combined with what we know of the area of Gabii, we can make a further inference about his estate. Cassius Dio reports that the soldiers became ill. It is very probable that the extended stay of the legionaries in marshy and maybe unhealthy places caused an epidemic. Although Gabii itself lay on high ground, the surrounding area includes the marsh of the Pantano Borghese. Archaeological surveys in the ager Gabinus have revealed tunnels for water drainage, 33 and a complex system of drainage, dating back to the mid-Republican period, has also been found in wo excavations in the ager Gabinus. ${ }^{34}$

The location of Postumius' estate near the town of Gabii is perhaps not unexpected: there were close connections from the fitth century B.C. between the gens Postumi with its interest in Greek cults, ${ }^{35}$ and the territory of Gabii, famous for its Greet culture, ${ }^{36}$ as well as for its importance in the augural field, although we do not know when any member of the gens got possession of land in the ager Gabim do not know

Roman colonization: Cassoly has recalls the critical phase of the early history of an activity of the gens and the ager acquired by an aristocratic group was colonized

Atlante tematico di in S. Quilici Gigli, Agricoltura e commerci nell' 'talia antica, ed. L. Quilic ${ }_{30}$ Coarelli (n 15), Topografia antica, Suppl. I (Rome, 1995), 120-1.

Coarelli (n. 26), 16-20; Almagro Gorbea (n. 29), 52-7, 589-91. H. Lauter in 'Ein Tempelgarten?; $A A$ (1968), 628-31, had noted this circumstance, but thought of the area as the ${ }^{32}$ Cato, $A$ gr 10 An olive

hile a group of 16 low grove of 240 iugera ( 60 hectares) needed 13 labourers to maintain it 2,000 soldiers is, therefore, remarkables ary for a vincyard of 100 iugera ( 25 hectares). The use of S. Musco, C. Morelli, and M.

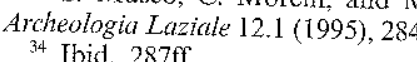

${ }_{35}^{34}$ Sidid, $287 \mathrm{ff}$.

G. Franciosi (ed.), Ricerche sulla postumia nella prima repubblica, Origini e politiche', in ${ }_{36}$ In 466 B.C. a Sp. Postumius dedicated the tentiliza romana III (Naples, 1995), $267-98$. reaty of isopoliteia between Gabii and Rome temple of Ditus Fidius Semo Suncus, where the E. Peruzzi, 'Romolo e le lettere greche', $P P 24$ (1969), 161-89; revised in id Orchicini period, see (Bologna, 1973), 9-53; id., 'Grecità del Lazio preromano', in id.. Civiltà greca nel Lazo preromano (Florence, 1998), 165-77.

corrupt passage of Macrobius date of 338 B.C. sulggested by Palmer (n. 4), 5, on the basis of mistranslates Dion. Hal. 17/18.41, 3.9.13), Palmer also, like the Loeb edition, clearly hereditary succession. directly by this group. ${ }^{38}$ This idea is very probable and agrees with Cornell's interdirectly by this gers pretation or Roman wa ager Gabinus may form part of this pattern.

A re the territory A venditio quaestoria is probable for Gabi, as 40 penedl-known fragment of Fabius or Cures Sabini, after the conqust of thati, an Pictor also suggests a radical change in Roman society in this period. ${ }^{41}$ in the particular case of Posturnits, his kinsman's defar at he Caldine Forks in 321 B.C., and his own difficulties over his triumph at the end or his earler consuship in 294 B.C. may have led him to put ambition before scruple (Liv. Lpit. 10.37.6-12). The economic development of the area of Gabii in general emerges from the discovery of a country villa, the first phase of which dates to the beginning of the third century B.C. ${ }^{43}$ Unfortunately, epigraphic documentation, completely absent in the area of the excavation, does not allow us to identify the owners.

\section{THE CONSUL'S BEHAVIOUR}

In due course, according to the Epitomae of Livy, Postumius was convicted for usin the labour of his soldiers during his consulship. Dionysius of Halicarnassus and the Suda also insist on the gravity of his action, while Cassius Dio reports that Postumius was recalled by the senate, because of the illness of his soldiers after cutting down the wood. Only Dionysius of Halicarnassus records that Postumius was condemned in the comitia tributa to pay a large fine. ${ }^{45}$

${ }^{38}$ F. Cassola, 'Aspetti sociali e politici della colonizzazione', DArch ser. 3, 6.2 (1988), 15-17; F. Coarelli, 'Colonizzzzione e municipalizzazione: tempi e modi', DArch ser. 1. J. Cornell, 'Rome an 'L esp. 274-94; M. H. Crawford, La storia della colonizzazione romana Lecondo 1 (Naples, 1995), $187-92$.

40 Sicul. Flace. De condic. agr. 102.35-104.3 Ca. $=100.8-13$ Th. $=136.14-19$ La. 118.26-120.17 Ca. $=116.20-118.10 \mathrm{Th} .=152.23-153.23 \mathrm{La} . ;$ Liber Coloniarum II 192.19-21 Ca $=253.17-19$ La.; Hygin. De condic. agr. 82.23-30 Ca $=78.18-79.4 \mathrm{Th} .=115.15-116.4 \mathrm{La}$. On the division of the ager Sabinus, see E. Gabba, 'Per un'interpretazione storica della centuriazione tol teritorio di Cures Sabini', RAL ser. 8 , 30 (1975), 223-30; ead., Cures Sabini, Forma Italiae, Regio IV 2 (Florence, 1980), 37-41; ead., 'Cures Sabini', in Misurare la terra: centuriazione e

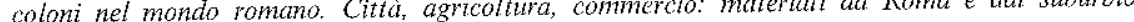
(Modena, 1985), 48-53.

${ }^{41}$ Strabo, 5.3.1 = fr. 20 Peter $=F G r H 809 \mathrm{~F}$ 27. On the fragment, see E. Gabba, 'Ricchezza e classe dirigente romana fra II e I sec. a.C.', RSI 92 (1981), 543; id., 'Riflessioni sulla della ricchezza. Saggi di storia economica e sociale del mondo antico (Milan, 1988), 45-8. Contra W. V. Harris, War and Imperialism in Republican Rome, 327-70 B.C. (Oxford, 1979), 65-7, 264.5. ${ }_{42}$ Palmer (n. 5), 12.

${ }^{43}$ Site G 11 , according to the numbering of A. Kahane and J. Ward Perkins, 'The Via Gabina', PBSR 40 (1972), 91-126. For the excavations, see M. Aylwin Cotton, 'Una villa ed un grande edificio romani lungo la via Gabina", Archeologia Laidall (ed), Ancient Roman Villa Gardens, Distory of Landscape Architecture 10 (Washington, DC, 1987), 223-60, esp. 227.

${ }^{44}$ I thank Professor M. G. Granino Cecere, responsible for the updating of $C I L \mathrm{XIV}$, for information on the epigraphic data from the ager Gabinus. Unfortunately in that area there is no epraphic evidence of the presence of the gens Postumia, even in the Imperial age.

the Dion 
Modern historians offer different opinions on the indictment and on the date of the
trial. For Mommsen, the reason for the conviction lies the soldiers for private reason for the conviction lies only in the use of the labour of hostile acc for of ther hand, prefers to follow the series of despotic acts callo It is very prob astumius during his consulship. ${ }^{47}$

onsulship Livy able that the trial was in 290 B.C., at the end of Postumius' third was anther the the 293 B.C., after his second consulship (in 294), there

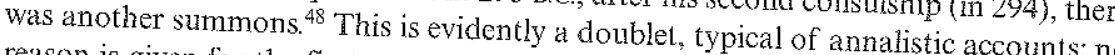
reason is given for the first supposed indictment and, immediately after Livy bin reports that no trial took place. The year $293 \mathrm{BC}$ is also less probale, becer Megellus was subsequently elected consul for $291 .{ }^{49}$

The episode of 291 B.C. is mentioned by Cassola as an example of disagreemen between consul and senate, along with others in which Postumius chim disagreemen acy of the consular imperium. ${ }^{50}$ To the accusation of abuse of authority the supremsoldiers, the consul answered that the senate did not nule of and his-à-vis the using words similar to those Dionysius attributes to him on aver him, but he over it," shows that his rebellious behaviour aginst the sen In his refusal to accept the supremecy of the left a deep mark on the tradition. tenaciously he was attached to the and of the senate, Postumius showed how that the holder of imperium to the ardacincle was an action typical of parion conservative nobility, topat it fan behaviour in the past; Postumius, as a member of a conservative nobility, took it for granted, but the new nobilitas, after a long process of On the could no longer act in such way.

the soldiers, Dionysius accuses the consul of arrogance and specifies (hat the sork like retainers and

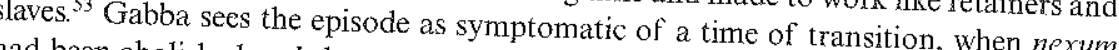
wad been abolished and the nature or clientage was changing but slawery was not ye widespread. He suggests that Postumius treated his soldiers as if they were old yet clientes. ${ }^{54}$ Traditionally clients had been obliged to do operoe, that is days of old-style

${ }_{47}^{46}$ T. Mommsen, Römisches Staatsrecht II.1, (Leipzig, 188733), 321

(Rome, 1906), 87-9, 102.

M. Scantio tribuno plebis fonguerat legattione, uo populum est L. Postumaterum legatum eius, qui dicta die a peragi accusatio eins' poterat. Postumius, in fact, to avoid the trial broum; iactarique magis quam Scantius supposedly agreed to become a legate of Sp. Carvilius in 293 ac dhe tribune Marcus ${ }_{49}$ So Binium.

${ }^{56}$ So Bruno (n. 47), 88, n. 3

agreement between Postumius and the senel III sec. A.C. (Trieste, 1962), 194-8. On the disconsenso e stato a Roma tra il 326 e il 264 a. $C$. Loteto, Un' epoca di buon senso. Decisione meccanismi della lotta politica a Roma tra il 314 e il 294 a C C Con), 121-2, 184, and id.. "S AFLM 24 (1991), 61-76, esp. 74

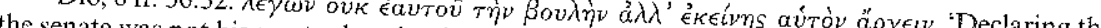
Dion. Hal 17/1845: bu that he was he master of the senate' (ed. Loeb I 287)-

that he governed the senate' (ed. Loeb VII 335-7).

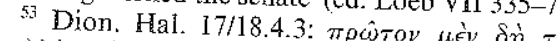

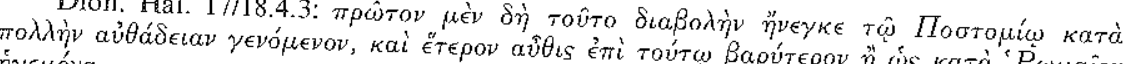
$\eta \gamma \in \mu$ ova.

fra III e IV secolo', in Storia di Roma. II.1. L'impero their patronus, ${ }^{55}$ just like nexi, who were subjected to their creditor and paid off thei debt with days of work. ${ }^{56}$ Such exploitation, typical of the fifth and fourth centuries BC, was still in use in the third century when an alternative and equally effective system had not yet been fully developed. The continued existence of forms of forced sybour imposed on free men, would suggest that the Roman nobility was opposed to labou, ining deep-rooted attitudes to dependent labour. Scullard observes that at the aband spread of large aristocratic estates begining of employment and made possible the extension of patronage, ind ${ }^{57}$

perhaps also, in some instances, grants of land. The episode of 291 B.C. clearly falls in a period of social tension. although the

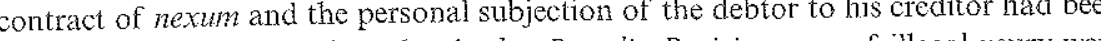
formally abolished in 326 B.C. by the lex Poetelia Papiria, cases of illegal usury were brought to trial in 296 B.C. (Liv. 10.23.11). In 287 B.C. a proposal for the remission of debts was opposed by the senate, giving rise to the fourth plebeian secession. ${ }^{8}$ The secession ended with the lex Hortensia, which established that plebiscites were to have the force of law. ${ }^{59}$ The dictator Quintus Hortensius managed to persuade the plebs, exhausted by debt, to leave the Janiculum. ${ }^{60}$ It is very probable that among the citizen who had rot into debt there were many small landowners who had been impoverished by the Samnite Wars ${ }^{61}$ The increasing number of Roman citizens excluded from by the Ste to the first extraordinary recruitment of capite censi equipped by the state. ${ }^{62}$

We could then see in the behaviour of the consul the legacy of practices characWe conld then see in the behaviour of the colving the use of a coniuratio, a kind of teristic of the sixth and fifth centuries B.C., involving the use of a coniuratio, a kind of private military organization, based on the voluntary service of commanders and soldiers. At the end of the sixth century, and at least in the first years of the fifth century B.C., the battles in which Rome was involved against neighbouring peoples were often personal wars, led by members of important and influential gentes, who could count on the support of their armed sodales and clientes. From this point of view the centuriate reform of Servius Tullius, created to

For the duties of clientes towards their patronts, see F. De Martino, 'Clienti e condizioni materiali in Roma Rome, 1980), 703-5.

S6 On the connection between army service and indebtedness, R. E. Mitchell, Patricians and were in reality soldiers who were clientes of important men, 'held captive in licu of ransom'.

${ }^{57}$ H. H. Scullard, Roman Politics 220-150 B.C. (Oxford, 1951), 13-14. On the general trend

Dio, fr. 37.2; Zonar. 8.2.1. On the episode, see the sources collected in Torelli (n. 4), 69-73. ${ }_{59}$ On the lex Hortensia, see G. Rotondi, Leges publicae populi Romani (Milan, 1912), 238-41. secoli della repubblica romana (Milan, 1981), 99; M. H. Crawford, Roman Republican Coinage (London, 1974), 610ff.

on Perioch. 11: Ptebs propter ces alienum post graves et longas seditiones ad ultimm secessit in laniculum, unde a $Q$. Hortensio dictatore deducta est, isque in ipso magistratu decessit.

${ }^{61}$ On the problem of debt as the real cause of the plebeian secession, see G. Maddox, 'The $63 . \mathrm{T}$ J Comell 'La guerra e tos origini di Roma (Pisa, 1988), 94ff. 
the main aristocratic oroun the sixch and the fifth centuries B.C. show that the patriciate, as the dominant feature of the with its gentilicial structure and client relations, was still well-known slaughter of social organization of Rome. One of these examples is the well-known slaughter of the Fabii and their clientes at the Cremera ${ }^{64}$ anples is the artival in Rome of the Sabine Claudii and the occupation of land along the Aner the their clientes (Suet. Tib. 1), and a third is represented the inscription recalling a Publizy Valerius and his $s(u)$ odales. ${ }^{55}$ The episode of Appius Herdonius, a Sabine Publius of fortune who in 460 B.C. tried to conquer Rome with an arnys, a Sabine soldier significant evidence for this type of social organization an army of clients, ${ }^{66}$ is also similarily attested in the Etruscan saga of the Viben in archaic Rome, which is Mastarna. ${ }^{6 ?}$

thenna brothers and their sodals are understandable. During the Postumius in the light of these examples, his actions completed and brought radical third century B.C. the evolution of the nobilitas was of the senate. However, it was normes in the command of the army and in the power more conservative part it was normal, as we can see in the episode of 291 B.C., for a Cornell has underlined during aristocracy to act as was typical in former centuries. ${ }^{68}$ As was chatic underlined, during the fifth century B.C., the governmental system of Rome Was chaotic and anarchic. ${ }^{69}$ These difficulties are clearly reflected in the of Rome accounts of the plebeian secessions, the problem of debt and famines; these last in particular probably come from a reland especially the many perhaps assume that, just as in that period, clientes and sodales tradition. ${ }^{70}$ We may patronus, their 'commander', in military actiontes and sodales normally followed their use these same people to carry out a ariculturn, so it was normal for the patronus to It is important to notice th ougricultural work

was still present and continued to third century B.C. indebtedness of the population 216 B.C., according to Livy and to affect military conscription of citizens. As late as insolvent debtors to enlist in the Valerius Maximus, an edict was issued that allowed cancellation of the debts of all eny. ${ }^{71}$ The dictator Marcus Junius Pera ordered the creditors after the debts of all enlisted soldiers who had been subjected to their creditors after being convicted of insolvency. The edict benefited not only insolvent ${ }^{64}$ The number of clicntes who supported the gen

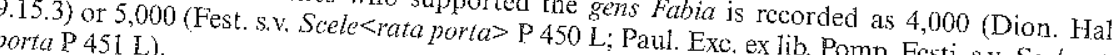
${ }_{65}$ See C. M. Stibbe, G. Colonna C. De Sin Archaeological, Epigraphical, Linnguistic and Histone, and H. S. Versnel, Lapis Satricunus Satricum (Rome, 1980); also C. Anoto ' $\mathrm{Ca}$ - citstorical Aspects of the New Inscription from pazio, il tempo, il sacro nella nuova realta cte Capitolitum atque arcem serve, ad duo mith ${ }^{67}$ On the Etruscan sage and its histore.

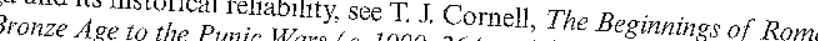

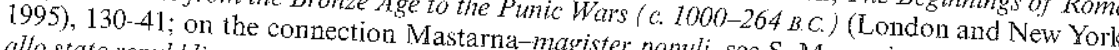
allo stato repubblicano; ricerche di storia romana arewica (C a s. S. Mazzarino, Dalla monurch nia, 1945, repr. Milan, 1992), 175-9.9, ${ }_{70}$ Cassola (n. 50), $197 . \quad{ }^{69}$ Cornell (n. 63), 97.

Quarto contributo alla storia degli studi classici e del maica', SDHI 2 (1936), 373-98, repr. in id id., Roma areaica (Florence 1989), 183-2057 Liv. 23.14.2-3: dictator M. 183 -207.

pecuniae iudicati in vinculis essent, qui eorum a.. edixititque qui capitalem fraudem ausi quique addictorvum etiom addictorum etiam et capitali crimine damnatorum sera dictatore rem publicum adminisugue sese debtors, but also men who had committed a capital offence. If they became soldiers under his command, the dictator would order their release from punishment or debt. The indictment of Postumius Megellus for abuse of authority seems strange and orced, especially if we consider other episodes of his life as reported by Livy, who presents him as a man always observant of conventions and rules. During his second consulship, in 294 B.C.. Megellus asked the senate for a triumph more as a matter of procedure and custom than in the hope of success. ${ }^{72}$ In the same way he forbade pe ins convention. If Postumius was recalled and contoted, the efence must be seen not in the abuse of authority in using soldiers, which might rather rencet the normal imposition of a kind of forced labour, but in the fact that they were kept on his estates for a long time and that in the end they became ill.

Unfortunately, our sources do not tell us how many soldiers out of the two housand died. In a period of heavy military commitment, during the Third Samnite War, any decrease in the number of soldiers would have been serious. A report of los or temporary indisposition would have obliged the senate to seek the causes. 'It was thought their trouble was due to the felling of the grove', according to Cassius Dio who clearly believes that the action provoked divine anger, despite the avoidance of iron tools we may more plausibly suppose that the territory of Gabii was at that time marshy and unhealthy 73

It is theoretically possible, given the number of soldiers used by Postumius, that he was also clearing ager publicus and applying a procedure that would become usual during the Imperial age, the use of milites as labourers for Roman public works. ${ }^{74}$ In any case his actions took place in an area of crucial importance for Rome, because it was the source of most of the water used in the city and many aqueducts ran through it. Let us consider Rome's second aqueduct, the Anio Vetus, which as we know from Frontinus was built between 272 and 269 B.C. $^{75}$ The censor Manius Curius Dentatus ${ }^{76}$ financed the work, using the spoils of war taken from Pyrrhus, ex manubiis de Pyrro captis. ${ }^{77}$ The aqueduct's course was mostly underground, from the high Anio valley

${ }^{72}$ Liv. 10.37.6: Ob hasce res gestas consul cum tritunphum ab senatu moris magis quam spe

${ }_{73}$ On the progressive degradation of the Latial agricultural landscape, see the useful observations of C. Yeo, 'The overgrazing of ranch-lands in ancient Italy', TAPA 79 (1948),
$275-307$; on malaria and the marshlands, sce the articles of P. Fraccaro in Opuscula II. Stud 275-307; on malaria and the marshlands, sce the articles of P. Fraccaro in Opuscula II. Stud
sull'età della rivoluzione romana, Scritti di diritto pubblico. Militariz (Pavia, 1957), 'La malaria e la storia degli antichi popoli classici', 337-67 and 'La malaria e la storia dell'Italia antica', 369-78; P. A. Brunt, ltalian Manpower 225 B.C.-A.D. 14 (Oxford, 1987), 611-24.

Gabba (n. 54), 9-1

${ }^{75}$ Aquaed. 6. Cfr. Auct. De vir ill, 33.9: Aquam Anienem de manubiis hostium in urbem induxit. For a comment on the passage, see H. B. Evans, Water Distribution in Ancient Rome. The
Evidence of Frontinus (Ann Arbor, 1994), 75-82 and C. Roncaioli Lamberti, 'Osservazioni o proposte sul sito dell' incile dell' Anio Vetus e sul ramo di derivazione dell' Anio Novus's in A. M. Liberati Silvcrio and G. Pisani Sartorio (edd.), Il rionfo dell' acqua. Atti del convegno' 'Gli antich acquedotti di Roma: problemi di conoscenza. conservazione e tutela' (Rome, 1992), 83.92; on the Anio Vetus, see T. Ashby, The Aqueducts of Ancient Rome (Oxford, 1935), 54-87; P. J. Aicher, Guide to the Aqueducts of Ancient Rome (Wauconda, 1995), 35-6.

the promoter of another important work of public uttlity, the partial draining of the Lago Velino, near Reate: Cic. Att. 4.15.5: lacus Velinus a
M. Curio emissus interciso monte in Nar<em> defthit, ex quo est illa sicccata et unida tamen modice Rosea. See G. Bodei Giglioni, Lavori pubblici e occupazione nell' antichità classica (Bologna. 1974), ${ }_{77}^{68-9}$ 
Praenestina. It ran along the via Praenestina town, from where it reached the via last along the via Labicana to the Porta Magrina Gabii, then along the via Latina and at through this area shows the complete cogs. The construction of the Anio Vetus suburbium.

The creation of a system of aqueducts and the restoration of the road network, a via Labicana, during the third centwry Quilici's studies of the ef the area, in comparison with the previous century.78 Quiltemes stut,

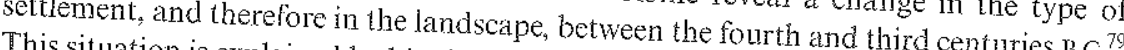
ho of

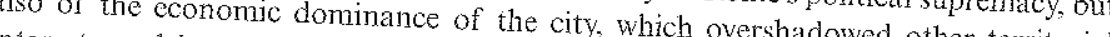
a the radial net of communications between tertorial outlying towns.

Ashby's studies of the Roman Campagna revealed a dense roat netwotk in area. ${ }^{80}$ Beside the via Praenestina, in the archaic period Rome to Gabii, putting the latter on the archaic period the via Gabina, ${ }^{8 t}$ that linked Campania, there were also many minor trade-route in the archaic age from Etruria to that linked Gabii to nearby centres sur roads, practically a secondary road network, Hills. ${ }^{82}$ We can see the function of favourable position where various of control that Gabii had, ${ }^{83}$ partly beciuse of its Campania, the old routes that limportant routes crossed, such as the inland route to coast, and the Etruria-Sabin axis the Abruzzo and the Adriatic to the Tyrrhenian and partly because of its interest in Gabil is the end the resulting Romen We should also not end subverted the reason for the interest.

all scale in the fould that lapis Gabmus was used in Rome for the first time on in the def he for the red Anio tufa which had been used in The widespread

to build public works, during the second century B.C., see E. Gabba 'Considerazioni politiche ed Mittelitalien, Kolloguium in Gäro in Italia nei secoli II e I a.C.', in P. Zanker (ed.), Hellenismus in the spoils were used, see $E$. Bona 'Sul concetto di uni 1974 $\mathrm{Cl}$, (Gottingen, 1976), 325. On how in ordine alla preda', SDHI $26(1960), 105-75$.

suburbio orientale tra il IV ed il I sec. a.C.', in Misurare (n. 40) 90-106.

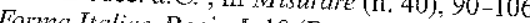

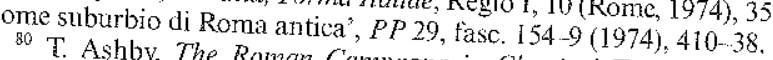

81 Liv, 2117. Roman 2.11.7, 3.6.7, 5.49.6 (some milestones of the via Gabina) See A, on Gabii, esp. 180-97. Roman road east from Gabii', PBSR 41 (1973), 18-44; G. Radke, Viae A. M. Kahbiane, 'A paved Sigismondi, (Bo Publicae Romanae (Stuttgart, 1971), cc. 1482-3, transluted into Itatue, in RE 78), 92-5.

comunicazioni tra Etruria e Magana, see S. Quilici Gigli, 'La valle del Sacco nel quadro delle degli insediamenti nelle valli del Sacco e del Liri in età pror, 363-6;, P. Sonmella, "Per uno studio recorelli, dind Bered secondary routes, that linked Gabii to nearby minor 297$), 393-407$. On ${ }_{33}$ orelli, and Brucchietti (n. 33), 275-92. Guaitoli (n. 1), 48-9.

Guaitoli (n. 1), 45ff, fig. n. 18, 6.1; Liv. 1.5 probably to be dated to the beginning of the second century B.C. ${ }^{86}$ From that time the quarried stone was partly used for the needs of the territory, but mostly exported to Rome to be used for public buildings (Strab. 5.3.11)

orks, the building of the Anio Vetus, and the quarrying of lapis Gabinus reveal that the area of Gabii and its territory was characterized by considerable economic activity at this time, and that it had become the object of urban economic interests. Rome more and more tended to change the aspect of its surrounding territory: perhaps we should consider Postumius' order to cut down trees as presaging the building of the Anio Vetus about twenty years later.

\section{SUMMARY OF CONCLUSIONS}

The discovery of a fragment of parchment indicating the site where the military activity of the consul Postumius took place, and especially where two thousand ldiers were sent, allows us to understand elements in other literary sources on the episode of 291 в. . That the consul's estate was large and also included, besides fields, acred grove and marshy areas, is a very probable hypothesis, because a morphological analysis of the soil around Gabii reveals that in antiquity the area was marshy, and included healing sanctuaries and the cult of a sacred tree in the temple of Juno Gabina, which wastounded by a lucus. The location of the consul's estate also Guges the abuse af a of authority. His ad tive This allows us to interpret his use of soldiers for personal aristocratic conservative. This allow ends as the appliction of trallional anstocratic mation, which were deep-rooted in the mentalty of conservalive paticins antions not ye been abandoned by men such as Postumitus. Other possible explanations may be sought in the urgent need to clear recently actirs personal Thancial difficultes (a menter of the gens Posm had heen dereated at the Caudine Forks), but also simply in the reclamation of marshy land overgrown with vegetation, or in deforestation before the building of an aqueduct or a new road, Florence

C. GABRIELL chantalgabrielli@virgilio.it

96 A. Balil, 'Topografia de Gabii y del Agro Gabino', Cuddernos Escuela Esp. de Hist. y Arq. 10 (Rome. 1957), 306-9. 